\title{
Transformasi Kulit Singkong Menjadi Nata de Cassava dan Biostarter Kompos di Kecamatan Jatipuro Karanganyar
}

\author{
Vita Ratri Cahyani ${ }^{1 *}$, Rofandi Hartanto ${ }^{2}$, Pardono ${ }^{3}$, Feriana Dwi Kurniawati ${ }^{4}$, Iqbal \\ Firmansyah $^{1}$, Kynthavi Paramitha Lakshitarsari ${ }^{1}$, Nadine Yuki Azzahra ${ }^{1}$ \\ ${ }^{1}$ Program Studi Ilmu Tanah, Fakultas Pertanian, Universitas Sebelas Maret \\ ${ }^{2}$ Program Studi Ilmu Teknologi Pangan, Fakultas Pertanian, Universitas Sebelas Maret \\ ${ }^{3}$ Program Studi Agroteknologi, Fakultas Pertanian, Universitas Sebelas Maret \\ ${ }^{4}$ Bidang Tanaman Pangan dan Hortikultura, Dinas Pertanian Pangan dan Perikanan, Kabupaten \\ Karanganyar \\ *Correspoding Author : vitaratri@staff.uns.ac.id \\ Dikirim : 30-05-2021 Diterima : 30-12-2021
}

\begin{abstract}
ABSTRAK
Kelompok Wanita Tani (KWT) Tani Waras V di Desa Jatisobo dan KWT Makmur di Desa Jatimulyo, Kecamatan Jatipuro telah memanfaatkan berlimpahnya singkong dengan mengolahnya menjadi rengginang dan mocaf. Kulit singkong yang mencapai $10 \%$ dari berat basah singkong merupakan sisa proses pembuatan rengginang singkong dan mocaf yang dibuang sebagai limbah. Tujuan kegiatan ini mentransfer inovasi teknologi tepat guna berupa transformasi kulit singkong menjadi nata de cassava dan biostarter kompos kepada ibu-ibu di 2 KWT tersebut. Metode kegiatan pengabdian mencakup 2 tahapan. Tahap I terdiri dari formulasi resep nata de cassava, isolasi mikroba dekomposer dari kulit singkong untuk biostarter kompos, preparasi bahan-bahan untuk didemontrasikan kepada 2 KWT. Tahap II yaitu pelaksanaan interaksi dengan mitra dalam kegiatan (1) penyuluhan prinsip-prinsip pengetahuan dan teknologi, peragaan prosedur pembuatan nata de cassava dan preparasi biostarter kompos, (2) kegiatan panen nata dan hasil isolasi mikroba dekomposer, dan (3) kegiatan aplikasi biostarter kompos. Hasil evaluasi kegiatan pengabdian menunjukkan bahwa anggota di 2 KWT sangat antusias ditunjukkan dengan 90-95\% anggota aktif mengikuti semua kegiatan pengabdian. Kedua KWT sudah melaksanakan semua tahapan pembuatan nata $(100 \%)$, mereka mampu mengembangkan berbagai variasi resep termasuk menggunakan bahan limbah lain dengan tingkat keberhasilan 90-95\%. Keuntungan ekonomis yang dapat diperoleh per resep media fermentasi nata diestimasikan sebesar Rp 51.500. Peserta kegiatan pengabdian juga diperdalam pemahaman dan kemampuannya dalam perbanyakan biostarter kompos untuk pembuatan pupuk organik sehat.
\end{abstract}

Kata kunci: kelompok wanita tani, mocaf, pengabdian masyarakat, penyuluhan pertanian, transformasi limbah

\section{Transformation of Cassava Peel into Nata de Cassava and Compost Biostarter in Jatipuro District Karanganyar}

\begin{abstract}
The Women Farmer Group (WFG) of Tani Waras V in Jatisobo Village and WFG Makmur in Jatimulyo Village of Jatipuro District have taken advantage of the abundance of cassava by processing it into rengginang and mocaf. The peel of cassava which reaches $10 \%$ of the wet weight of the cassava is the main waste in these productions. The purpose of this community service activity was to transfer the technology innovation to turn the cassava peel into "nata de cassava" and "compost biostarter" to the 2 WFGs. The service activity consisted of 2 phases. Phase I was the formulation of nata de cassava recipes, isolation of decomposer microbes from cassava peel for biostarter compost, and preparation of materials to be demonstrated to WFGs. Phase II was carried out with partners (1) delivering principal knowledge and technology, demonstrating the procedure
\end{abstract}


of making nata de cassava and preparing compost biostarter (2) harvesting nata and isolates of decomposer microbes, and (3) application of compost biostarter. The evaluation results showed that the WFG members were very enthusiastic, as indicated by $90-95 \%$ of the members actively participated in all activities. They had performed the whole procedure of making nata (100\%), moreover they were able to develop various recipes including using other waste materials with a success rate of 90-95\%. The economic profit per recipe for nata fermentation media was estimated at $\mathrm{Rp}$ 51,500. Participants in the service activity also deepened their understanding and ability in the propagation of compost biostarter to produce healthy organic fertilizers.

Keywords: agricultural extension, community service, mocaf, waste transformation, women farmer group

\section{PENDAHULUAN}

Singkong merupakan salah satu tanaman andalan utama bagi petani di Kecamatan Jatipuro, Kabupaten Karanganyar. Menurut Badan Pusat Statistik pada tahun 2016, Kecamatan Jatipuro menunjukkan produksi singkong tertinggi di Kabupaten Karanganyar yang mencapai 15.941 ton (BPS Kabupaten Karanganyar, 2018). Tingginya produksi singkong di Kecamatan Jatipuro telah dimanfaatkan oleh ibu-ibu Kelompok Wanita Tani (KWT) di Kecamatan Jatipuro, khususnya oleh KWT Tani Waras V di Desa Jatisobo yang memproduksi rengginang singkong dan KWT Makmur di Desa Jatimulyo yang mengolah singkong menjadi mocaf (modified cassafa fluor).

Pada saat musim panen singkong, KWT Tani Waras V dan KWT Makmur, masing masing mampu mengolah sekitar 25 kuintal singkong per bulan untuk dijadikan $100 \mathrm{~kg}$ mocaf dan $100 \mathrm{~kg}$ rengginang singkong. Kulit singkong sisa pembuatan mocaf dan rengginang singkong selama ini hanya dibuang percuma sebagai limbah. Limbah kulit singkong jika tidak dimanfaatkan dengan tepat akan menimbulkan masalah pencemaran yang semakin parah.

Kulit singkong mencapai $10 \%$ dari berat basah singkong, kulit singkong merupakan sumber daya potensial yang penting jika dimanfaatkan dengan tepat secara teknologi (Oboh, 2006). Untuk pemanfaatan kulit singkong diperlukan inovasi teknologi tepat guna dengan memperhatikan kandungan nutrisi dan komposisi senyawa organiknya.

Kulit singkong terdiri 2 (dua) lapisan, yaitu lapisan dalam yang tebal berwarna putih dan lapisan luar yang tipis kasar berwarna coklat tua. Lapisan kulit singkong bagian dalam yang tebal dan berwarna putih mengandung protein kasar $(5,29 \%)$ (Akanbi at al., 2007) dan karbohidrat (4,55\%) (Resimanuk at al., 2018).
Kandungan karbohidrat pada kulit singkong dapat dimanfaatkan sebagai sumber energi bagi mikroorganisme dalam proses fermentasi. Fermentasi merupakan salah satu cara detoksifikasi kandungan sianida dan menurunkan kandungan serat kasar pada kulit singkong dan dapat meningkatkan kualitas protein singkong (Cardoso at al., 2005). Kandungan nutrisi tersebut menjadikan kulit singkong lapisan dalam memiliki potensi untuk diolah menjadi produk pangan "nata" dengan nama nata de cassava melalui fermentasi dengan bakteri Acetobacter xylinum yang mempunyai nilai fungsional gizi dan bernilai jual menguntungkan. Selama ini limbah singkong yang sudah dimanfaatkan dengan diolah menjadi nata de cassava adalah limbah cair tapioka (Alfarisi at al., 2021), limbah cair rengginang singkong (Permatasari at al., 2019), dan limbah ampas basah tapioka (Mayasti \& Nugroho, 2013).

Alternatif lain, kulit singkong berpotensi dimanfaatkan sebagai sumber isolat dekomposer lignoselulitik untuk biostarter kompos. Limbah kulit singkong memiliki kandungan lignin 7,2\%, selulola $13,8 \%$ dan hemiselulosa $11 \%$ (Sandi, 2010). Hal tersebut menunjukkan bahwa kulit singkong termasuk bahan organik yang sulit terdekomposisi. Bahan pengurai lignoselulosa bisa diperoleh dari berbagai sumber seperti tangkai kayu, daun dan kulit kayu (Anindyawati, 2010). Isolat yang diperoleh dari sumber kulit singkong diestimasikan memperkaya keragaman hayati dekomposer yang bermanfaat untuk pengomposan, seperti yang diperoleh dari hasil deteksi common dan specific mikrobiota dalam proses pengomposan jerami padi (Cahyani at al., 2002; 2003; 2004a; 2004b; 2009)

Tujuan kegiatan pengabdian ini adalah mentransfer inovasi teknologi tepat guna (TTG) berupa transformasi kulit singkong limbah mocaf dan rengginang singkong menjadi nata de cassava dan biostarter kompos kepada KWT 
Tani Waras V dan KWT Makmur di Kecamatan Jatipuro, Karanganyar, sehingga mitra memperoleh pengetahuan, pemahaman, kemampuan praktik ( $s k i l l)$ dalam memanfaatkan limbah kulit singkong menjadi produk yang mempunyai nilai fungsional dan nilai ekonomis secara mandiri dan berkelanjutan.

\section{METODE}

Mitra dalam kegiatan pengabdian ini adalah ibu-ibu petani dari 2 KWT, yaitu KWT Tani Waras $\mathrm{V}$ produsen rengginang singkong di Desa Jatisobo dan KWT Makmur produsen mocaf di Desa Jatimulyo, Kecamatan Jatipuro, Kabupaten Karanganyar, Provinsi Jawa Tengah.

Metode kegiatan pengabdian terdiri dari 2 tahapan, yaitu Tahap Pelaksanaan I meliputi formulasi resep pembuatan nata de cassava dan isolasi dan perbanyakan mikroba dekomposer lignoselulolitik dari kulit singkong untuk dijadikan induk biostarter kompos, dilanjutkan dengan preparasi bahan untuk peragaan saat penyuluhan dan bahan-bahan yang untuk diserahkan ke semua ibu-ibu KWT untuk pelatihan/praktik. Tahap Pelaksanaan II yaitu pelaksanaan berinteraksi dengan mitra ibu-ibu 2 KWT dalam beberapa kali pertemuan meliputi (1) kegiatan penyuluhan, peragaan dan praktik bersama pembuatan nata de cassava dan penyuluhan tentang biostarter kompos, proses pengomposan dan produk kompos sehat, (2) kegiatan panen nata dan peragaan hasil isolasi mikroba dekomposer dari kulit singkong, dan (3) kegiatan aplikasi biostarter kompos bersamaan dengan rapat evaluasi dan rancangan keberlanjutan.

Pada saat penyuluhan, peragaan dan praktik bersama pembuatan nata, ibu-ibu KWT diberi bahan utama (starter/bibit nata, gula, asam cuka) dan juga diberi wadah fermentasi per orang, selanjutnya saat panen nata ibu-ibu KWT diberi lagi starter/bibit nata untuk pengembangan, sedangkan saat praktik biostarter kompos, petani diberi bahan induk biostarter dekomposernya. Sedangkan bahan kompos dipersiapkan oleh ibu-ibu dibantu bapak-bapak petani.

\section{HASIL DAN PEMBAHASAN}

\section{Tahap Pelaksanaan I}

\section{Formulasi resep pembuatan nata cassava dari kulit singkong (bagian dalam)}

Untuk formulasi resep pembuatan nata de cassava dari kulit singkong, dilakukan percobaan pengujian proporsi bahan dan prosedur penyiapan kulit singkong lapisan dalam yang berwarna putih untuk digunakan sebagai media fermentasi hingga diperoleh prosedur dan resep (inovasi TTG) pembuatan nata de cassava yang menghasilkan bacterial cellulose nata yang optimal. Proporsi bahan yang optimal diperoleh dengan proporsi 100 gram kulit singkong yang sudah dihaluskan dicampur dengan $2 \mathrm{~L}$ air. Setelah proses pengendapan, larutan supernatannya digunakan sebagai media fermentasi. Resep untuk tiap 1 L media fermentasi, dilengkapi dengan $100 \mathrm{~g}$ gula pasir, $100 \mathrm{~mL}$ ekstrak tauge, $50 \mathrm{~mL}$ cuka $25 \%$, dan starter nata $75 \mathrm{~mL}$ (Gambar 1a). Hasil inkubasi selama 11 hari sudah diperoleh ketebalan nata $1,5 \mathrm{~cm}$ yang setara dengan media fermentasi yang dibuat dari bahan utama singkong (Gambar 1b).

Nata yang terbentuk selanjutnya dipanen, dicuci, direndam hingga bau dan rasa masam hilang, dan kemudian direbus dengan air gula atau sirup siap dikonsumsi.
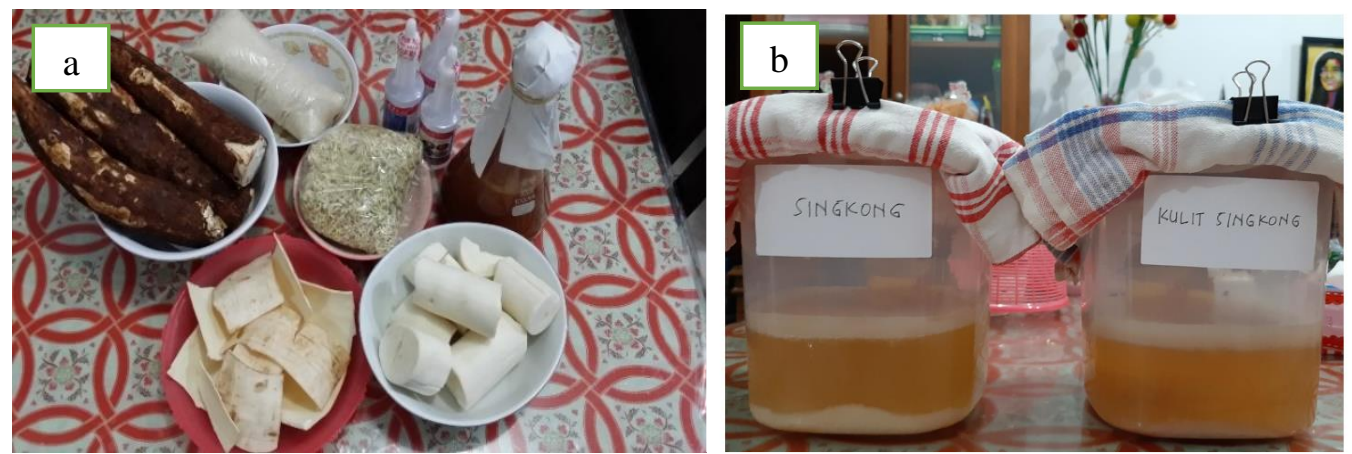

Gambar 1. Bahan-bahan untuk pengujian formulasi resep nata de cassava (a), hasil percobaan pengujian formulasi resep pembuatan nata de cassava dari kulit singkong (lapisan dalam), setelah inkubasi 11 hari menunjukkan ketebalan yang setara dengan nata dari singkong (b) 
Pengujian organoleptik mencakup bau, rasa, dan kekenyalan menunjukkan nata hasil formulasi resep uji coba tidak berbeda dengan nata yang dibuat dari bahan air limbah kelapa.

\section{Isolasi dan perbanyakan mikroba dekomposer lignoselulolitik dari kulit singkong}

Isolasi bakteri dan fungi menggunakan sumber isolat dari kulit singkong bagian kulit luar dan kulit dalam, dan juga dari bagian bonggol. Media isolasi yang digunakan ada 4 macam, Potato Dextrosa Agar (PDA), media lignoselulitik, media Carboxylmethyl Cellulose (CMC), dan media Omeliansky. Semua isolat kemudian disub-kultur dan diperbanyak di media cair PDA. Selanjutnya kultur campuran isolat dari kulit singkong ditambah dengan kultur stok dekomposer tim peneliti untuk memenuhi dosis yang diperlukan $500 \mathrm{~mL} / 25 \mathrm{~kg}$ bahan kompos. Kemudian diaplikasikan dalam tumpukan jerami padi yang telah memasuki fase pertengahan (middle stage) dalam proses pengomposan (Cahyani at al., 2002; 2003; $2004 \mathrm{a} ; 2004 \mathrm{~b} ; 2009)$ dan proses pengomposan dilanjutkan hingga 60 hari.

$$
\text { Semua proses penyiapan }
$$

didokumentasikan dan disampaikan ke ibu-ibu

KWT saat penyuluhan. Isolat hasil sub-kultur ditunjukkan dalam penyuluhan (Gambar 2). Hasil dari produk kompos jerami padi yang memperoleh perlakuan penambahan kultur cam-

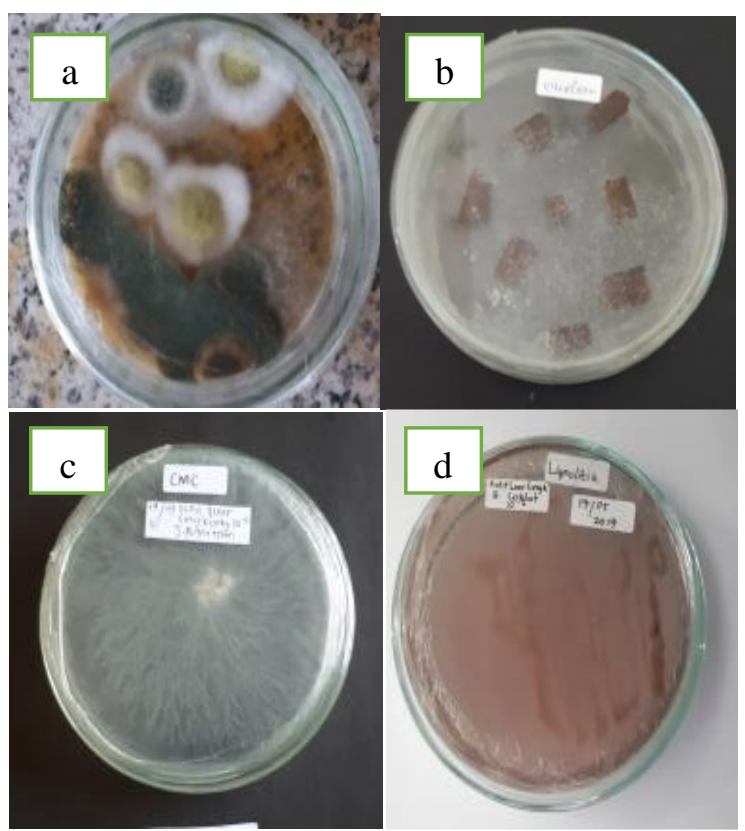

Gambar 2. Isolat dari kulit singkong pada media

PDA (a), Omeliansky (b), CMC (c), dan lignolitik (d) puran isolat kulit singkong menjadi biostarter kompos yang untuk diberikan ke ibu-ibu KWT untuk bahan praktik bersama perbanyakan dekomposer melalui pengomposan.

\section{Tahap Pelaksanaan II}

Penyuluhan, peragaan dan praktik pembuatan nata de cassava dan penyuluhan tentang biostarter kompos

Kegiatan penyuluhan, peragaan dan praktik pembuatan nata de cassava dan penyuluhan tentang biostarter kompos dilaksanakan pada tanggal 1 Mei 2019 untuk 2 KWT secara terpisah karena lokasi dua desa yang cukup jauh. Sesi pagi yaitu jam 09.0011.30 WIB kegiatan penyuluhan, peragaan dan praktik dilaksanakan di rumah Ketua KWT Tani Waras V di Desa Jatisobo (Gambar 3a dan 3b) dan dilanjutkan sesi siang jam 12.30-15.00 WIB di rumah Ketua KWT Makmur di Desa Jatimulyo, Kecamatan Jatipuro, Kabupaten Karanganyar (Gambar 3c dan 3d). Peserta yang hadir pada tiap KWT sekitar 40 orang, terdiri atas anggota KWT 20-25 orang, perwakilan bapak anggota kelompok tani desa setempat, ditambah Pamong Desa, Petugas Penyuluh Pertanian Kecamatan Jatipuro, staf dari Bidang Tanaman Pangan dan Hortikultura Dinas Pertanian Pangan dan Perikanan Kabupaten Karanganyar.

Materi penyuluhan dijelaskan menggunakan media LCD proyektor, setiap peserta juga diberi salinan materi. Materi penyuluhan meliputi : (1) potensi kulit singkong yang berlimpah yang belum dimanfaatkan, (2) pengertian tentang nata, (3) cara pembuatan nata de cassava, dan (4) alternatif bahan fermentasi lain yang dapat digunakan seperti: air cucian beras (air leri), ekstrak kulit buah-buahan, (5) penyuluhan tentang kegunaan kompos dalam pertanian berkelanjutan dan tentang pentingnya biostarter kompos dalam proses pengomposan untuk menghasilkan produk kompos yang sehat. Untuk praktik pembuatan nata, setiap peserta KWT diberi wadah fermentasi dilengkapi bahan gula pasir, asam cuka dan starter/bibit nata (Gambar 4a), baik di KWT Tani Waras V (Gambar 4b) maupun KWT Makmur (Gambar 4c). Ekstrak tauge disiapkan oleh Ibu Ketua KWT. Peserta diberikan contoh peragaan membuat nata de cassava dan dilanjutkan beberapa peserta mengikuti praktik di tempat, tetapi sebagian besar peserta sepakat untuk praktik bersama di lain hari saat agenda kegiatan KWT. 


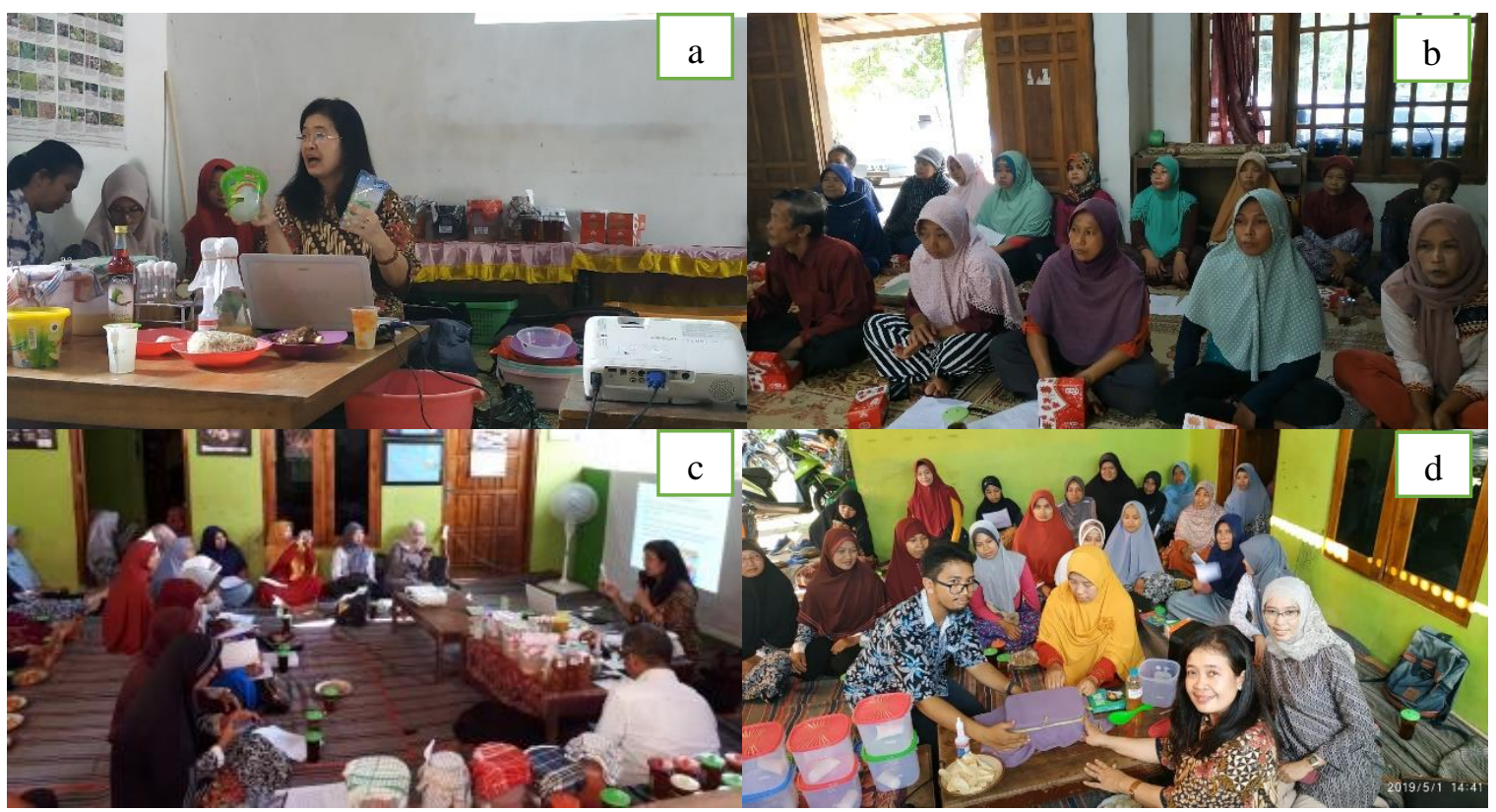

Gambar 3. Penyuluhan, peragaan dan praktik pembuatan nata de cassava di KWT Tani Waras V Desa Jatisobo (a \& b) dan KWT Makmur Desa Jatimulyo (c \& d)

Setelah menerima materi penyuluhan ibuibu dari KWT Tani Waras V (Gambar 5a) dan KWT Makmur (Gambar 5b) sangat antusias mempraktikkan pembuatan nata de cassava dari kulit singkong secara bersama-sama. Hal ini ditunjukkan dari laporan Ketua KWT melalui komunikasi whatsapp dengan mengirimkan foto saat mereka praktik bersama. Keingintahuan para anggota KWT juga sangat tinggi, hal ini ditunjukkan saat praktik mandiri mereka berinisiatif menggunakan berbagai bahan lain sebagai media fermentasi sebagai perbandingan seperti: media dari limbah cair mocaf, limbah cair rengginang, air cucian beras (leri), ekstrak kulit wortel, buah pepaya, ekstrak kulit buah melon, semangka, dan jambu.

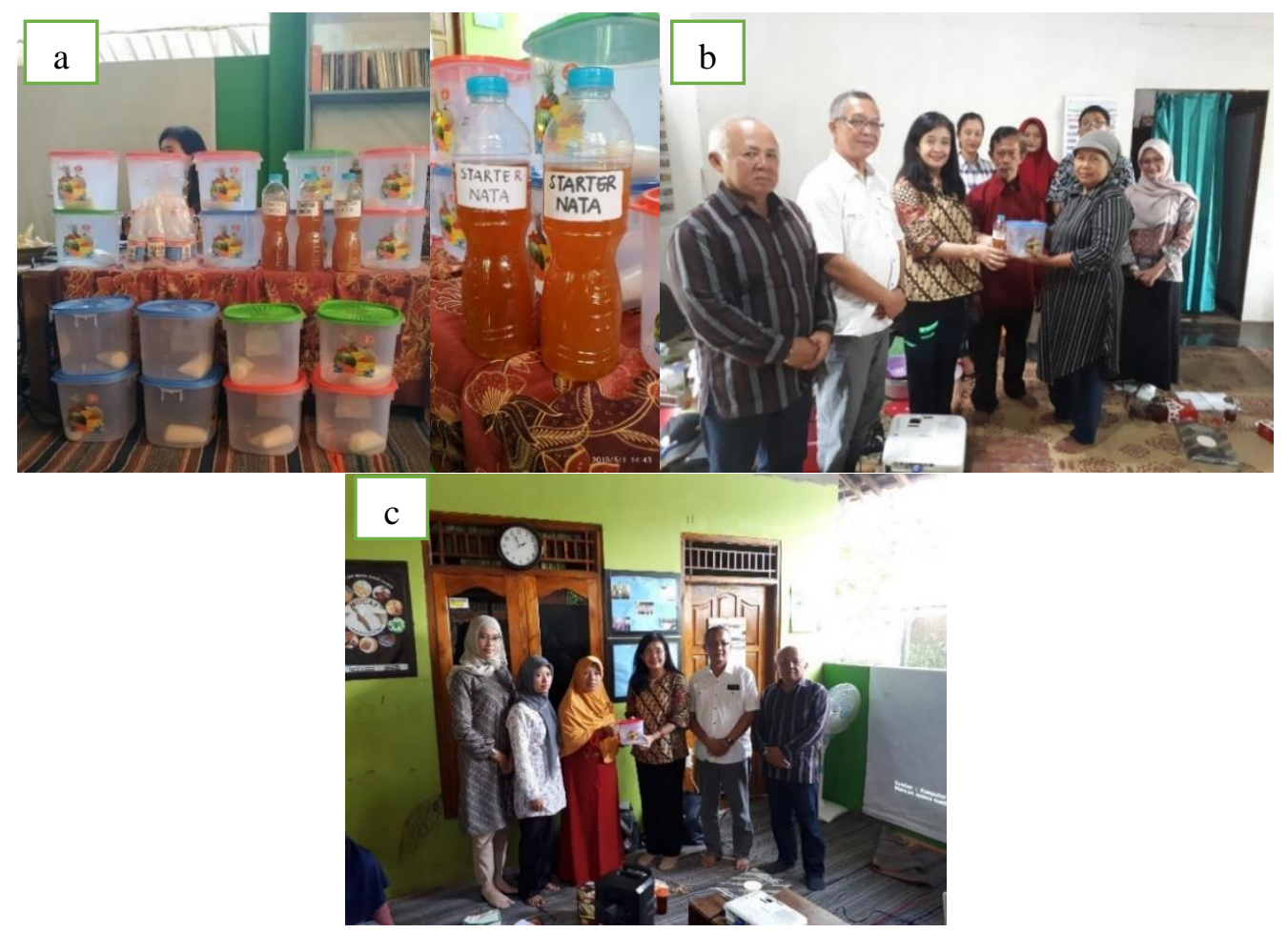

Gambar 4. Penyerahan perangkat pembuatan nata de cassava; (a) bahan dan wadah fermentasi nata (b) penyerahan kepada Ibu Ketua KWT Tani Waras V dan (c) penyerahan kepada Ibu Ketua KWT Makmur 


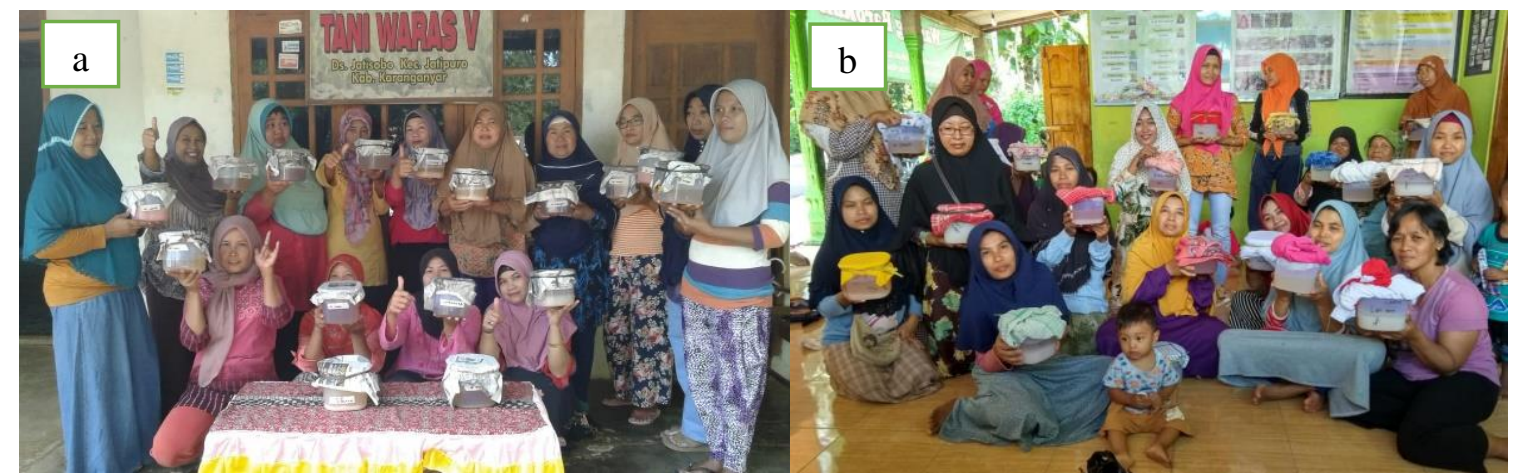

Gambar 5. Praktik mandiri membuat nata de cassava dari kulit singkong dan nata dari bahan fermentasi lain oleh KWT Tani Waras V (a) dan KWT Makmur (b)

Panen nata de cassava dan peragaan hasil isolasi mikroba dekomposer dari kulit singkong

Setelah proses inkubasi nata berlangsung sekitar 3 minggu, pada tanggal 27 Mei 2019 dilakukan kegiatan pengamatan dan pemanenan nata de cassava di KWT Tani Waras V dan KWT Makmur secara terpisah berurutan. Sesi pagi jam 09.30 - 12.00 kegiatan di KWT Tani Waras $\mathrm{V}$, dilanjutkan sesi siang jam 12.30 15.00 WIB kegiatan di KWT Makmur.

Pada KWT Tani Waras V dari 20 wadah fermentasi yang dibuat ibu-ibu KWT, ditemukan 2 wadah fermentasi yang tidak terbentuk nata dengan baik, sedangkan pada KWT Tani Makmur dari 20 wadah fermentasi hanya ditemukan 1 wadah yang tidak terbentuk nata. Kegagalan proses pembentukan nata pada kedua KWT tersebut dikarenakan beberapa faktor, yaitu (1) adanya semut-semut di dalam wadah yang disertai tumbuh jamur di sebagian lapisan nata bagian atas, (2) media fermentasi yang dibuat tidak mengikuti protokol, yaitu ekstrak kulit singkong yang langsung dipakai tanpa proses pengendapan dan pemisahan dari endapan, dan (3) proporsi kulit singkong tidak mengikuti protokol, porsi kulit singkong terlalu tinggi sehingga media terlalu pekat. Peserta memperoleh contoh pengalaman yang berharga untuk lebih memahami bahwa faktor kebersihan saat bekerja dan faktor formula resep sangat menentukan keberhasilan pembentukan nata.

Pada wadah fermentasi yang terbentuk nata dengan baik, dilakukan pemanenan bersama, diawali pengukuran ketebalan nata dan berat nata. Lapisan tipis bagian bawah nata dikelupas dan dicampur dengan sisa media fermentasi yang selanjutnya campuran ini dijadikan sebagai starter/bibit untuk pembuatan nata pada media fermentasi yang baru. Misal, sisa media fermentasi $500 \mathrm{~mL}$, maka dapat dijadikan starter/bibit untuk $6-7$ resep media fermentasi yang baru (1 L media fermentasi per formula resep). Dari tiap wadah fermentasi nata yang dibuat ibu-ibu KWT Tani Waras V (Gambar 6a dan 6b) dan ibu-ibu KWT Makmur (Gambar 6c dan 6d), baik yang menggunakan bahan kulit singkong (bagian dalam) dan juga bahan limbah lain (limbah buah-buahan, air leri, dan limbah cair mocaf dan limbah cair rengginang singkong

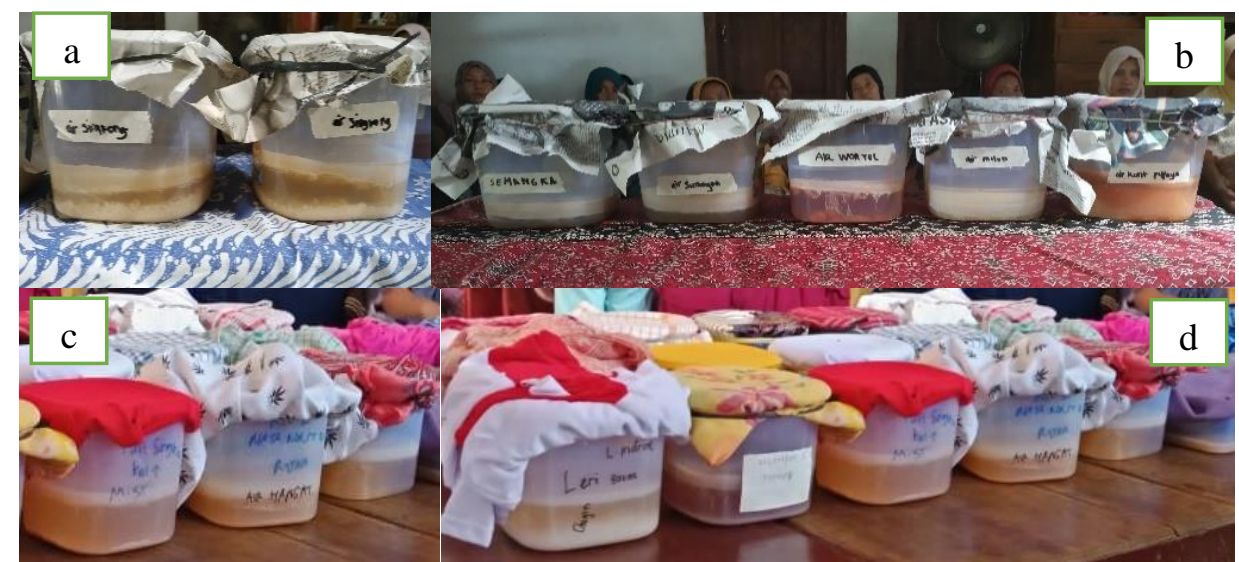

Gambar 6. Hasil panen nata de cassava dan nata dari bahan lainnya dari KWT Tani Waras V (a \& b) dan KWT Makmur (c \& d) 


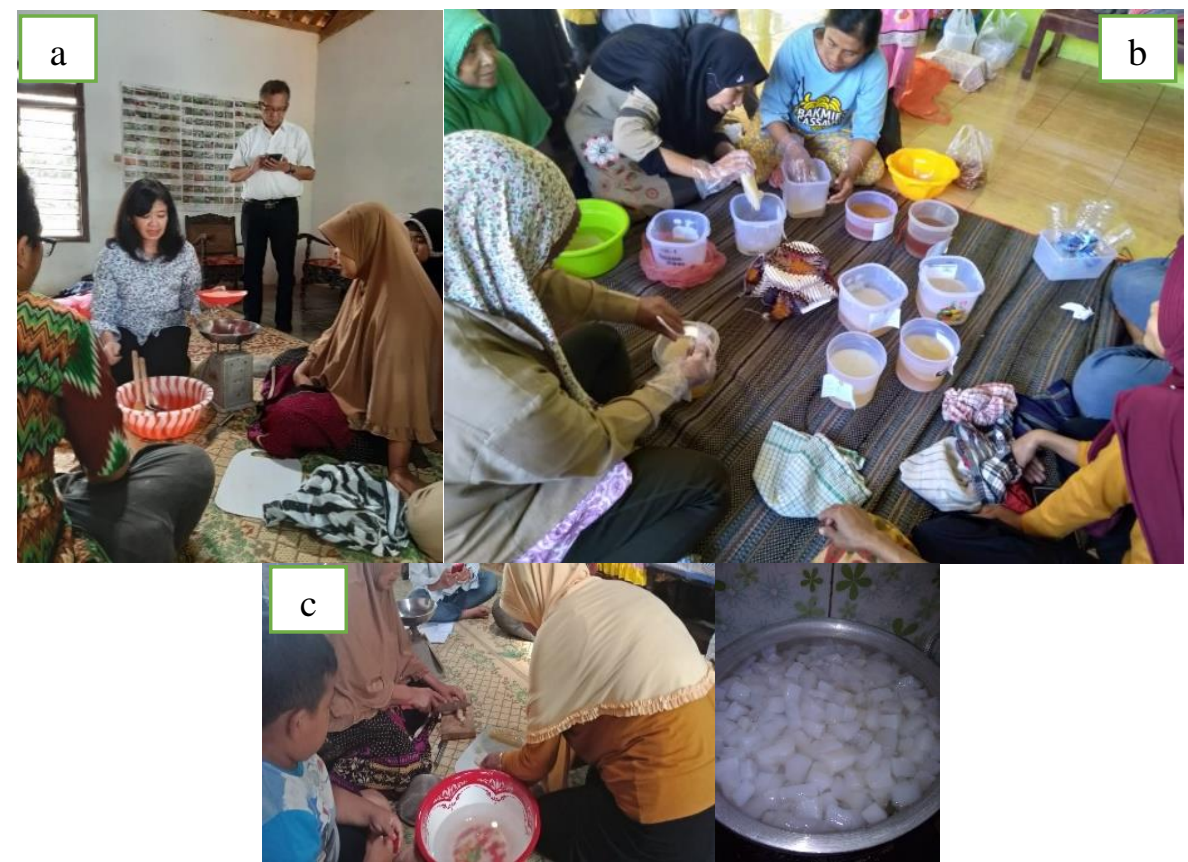

Gambar 7. Pengamatan tebal dan berat nata (a), pelepasan lapisan tipis paling bawah (b), pemotongan nata dan perendaman nata dalam air (c)

diperoleh hasil nata dengan ketebalan sekitar 1,5 $-3,5 \mathrm{~cm}$, dan berat segar sekitar $200-400 \mathrm{~g}$ per wadah fermentasi (Gambar 7a). Nata hasil panen selanjutnya dipisahkan lapisan tipis paling bawah (Gambar 7b), dipotong dadu (Gambar 7c), dicuci dan direndam air (Gambar 7d).

Selanjutnya Ibu-ibu kedua KWT diberi arahan untuk melanjutkan proses pengolahan nata secara mandiri, yaitu untuk meneruskan proses perendaman nata selama kira-kira 3 hari, dengan perlakuan tiap hari air rendaman diganti untuk menghilangkan bau asamnya. Setelah bau asam hilang, nata direbus, rebusan pertama air rebusannya biasanya masih berasa masam, sehingga air rebusan dibuang. Pada rebusan selanjutnya dapat ditambahkan larutan gula dan esens sesuai selera. Pada tahap ini nata sudah dapat dikonsumsi. Nata yang sudah diolah tersebut dapat disimpan di kulkas atau selanjutnya dikemas dalam beragam bentuk kemasan, seperti dalam kantong plastik atau dimasukkan dalam kemasan wadah gelas atau pot plastik seperti yang biasa ditemukan di pasaran. Nata yang disimpan dan/atau dikemas tersebut dalam bentuk direndam dalam larutan gula atau sirup. Nata yang diolah dengan baik dan secara higienis, dengan disiplin menjaga kebersihan dalam tiap tahap proses, tanpa menggunakan pengawet, dapat disimpan hingga 1 (satu) bulan dalam kulkas.

Ibu-ibu anggota KWT Tani Waras V Desa Jatisobo dan KWT Makmur Desa Jatimulyo pada saat kegiatan panen nata ini, selain dapat memanfaatkan sisa fermentasi untuk starter/bibit pembuatan nata selanjutnya juga diberi lagi starter/bibit nata yang baru, yang diarahkan untuk pengembangan ke pembuatan yang lebih banyak.

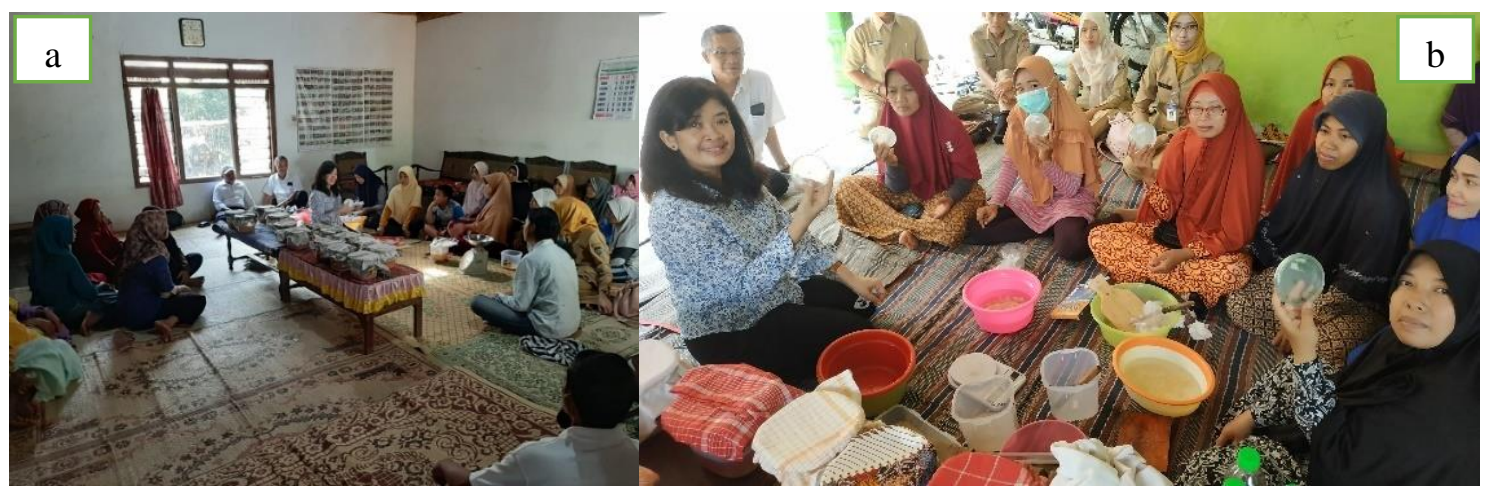

Gambar 8. Peragaan hasil kultur isolat dari kulit singkong untuk biostarter kompos di KWT Tani Waras V (a) dan di KWT Makmur (b) 


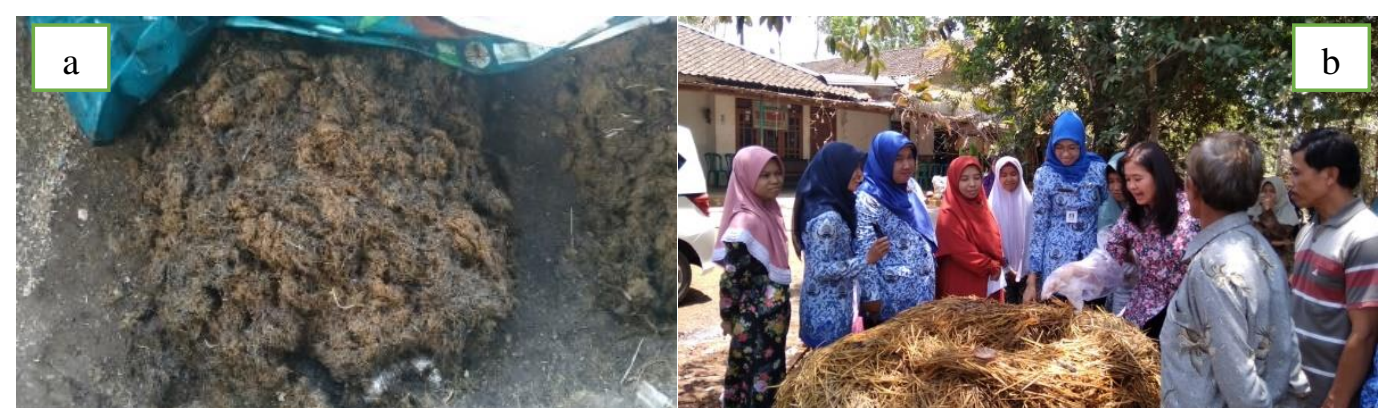

Gambar 9. Biostarter kompos (a) dan praktik aplikasi biostarter kompos pada tumpukan kompos jerami padi yang telah melewati fase termofilik (b)

Pada saat pemanenan nata ini, kepada ibu-ibu di 2 KWT (Gambar 8a dan 8b) diberikan penjelasan tentang proses pembuatan biostarter kompos dari kulit singkong dan ditunjukkan contoh isolat dekomposer dari kulit singkong dan sedang diperbanyak dalam kompos jerami padi di Laboratorium Biologi dan Bioteknologi Tanah, Fakultas Pertanian, Universitas Sebelas Maret.

\section{Aplikasi biostarter kompos, rapat evaluasi dan rancangan keberlanjutan}

Rapat evaluasi pelaksanaan kegiatan pengabdian dilaksanakan pada tanggal 17 Oktober 2019 jam 09.30 - 12.00 WIB secara bersama dengan menggabung ibu-ibu KWT Tani Waras V dan ibu-ibu KWT Makmur berkumpul di rumah Ketua KWT Tani Waras V Desa Jatisobo. Pada rapat evaluasi ini hadir juga bapak-bapak Kelompok Tani (KT) perwakilan desa setempat, Pamong Desa, Petugas Penyuluh Pertanian Kecamatan Jatipuro, Staf dari Bidang Tanaman Pangan dan Hortikultura Dinas Pertanian Pangan dan Perikanan Kabupaten Karanganyar.

Sebelum rapat evaluasi, kegiatan diawali dengan aplikasi biostarter kompos (Gambar 9a). ke dalam tumpukan kompos jerami padi yang sudah melewati fase termofilik. Tumpukan kompos jerami tersebut (Gambar 9b) sudah disiapkan ibu-ibu KWT dan bapak-bapak perwakilan KT 2 (dua) minggu sebelumnya. Hasil kompos jerami padi jika dipanen saat akhir middle stage atau awal curing stage (Cahyani at al., 2002; 2003; 2004a; 2004b) akan menjadi biostarter kompos selanjutnya.

Setelah aplikasi biostarter kompos selesai, kegiatan dilanjutkan dengan rapat evaluasi dan rancangan keberlanjutan (Gambar 10a dan 10b). Pada kesempatan ini, dibuka diskusi seluasluasnya untuk membahas hal-hal yang menjadi kendala atau kesulitan bagi ibu-ibu KWT Tani Waras V dan KWT Makmur tentang semua materi pemahaman maupun hal-hal praktis dalam kegiatan yang sudah terlaksana. Terkait pembuatan nata de cassava, beberapa ibu-ibu kedua KWT menyatakan kesulitan menggunakan starter/bibit hasil sisa fermentasi karena tidak dapat disimpan lama. Mereka melaporkan bahwa setelah nata dipanen, sisa media fermentasi yang dibiarkan seminggu, teryata muncul jamur kontaminan.

Ibu-ibu KWT diberikan penjelasan bahwa setelah nata terbentuk dengan ketebalan optimal sekitar $2-3 \mathrm{~cm}$, maka jika sisa media fermentasi masih cukup nutrisi dan $\mathrm{pH}$ masih berkisar 4 5 yang masih optimal bakteri nata yaitu Acetobacter xylinum (Mayasti \& Nugroho, 2013), maka dimungkinkan sisa media fermentasi masih akan membentuk nata lagi, asal saat panen pertama dilakukan dengan higienis, menggunakan alat yang bersih, tidak ada sumber kontaminan yang masuk, dijaga semut atau serangga tidak masuk wadah. Alternatif lain, jika setelah panen pertama nutrisi menipis dan terjadi peningkatan $\mathrm{pH}$ sehingga kondisi tidak ideal bagi bakteri nata maka akan muncul mikroba lain yang mendominasi kondisi. Oleh karena itu, setelah panen sebaiknya sisa media dipindah sebagai starter/bibit ke media fermentasi yang baru supaya bakteri nata dapat berfungsi berkelanjutan.

Terkait dengan biostarter kompos, Ibu-ibu KWT dan bapak-bapak perwakilan KT (Gambar 10) menyampaikan kesulitan untuk memperoleh jerami padi karena tidak semua mitra mempunyai sawah. Tentang hal ini, mitra diberi penjelasan bahwa pembuatan kompos tidak hanya terbatas untuk jerami padi, tetapi ada berbagai bahan organik yang potensial untuk digunakan, antara lain yang banyak dimiliki mitra adalah seresah sisa pekarangan, kotoran ayam, sisa dapur, sisa tanaman jagung, kacang tanah, sisa tanaman jahe, kunyit yang banyak ditanam mitra, bahkan sejenis gulma kirinyuh juga dapat digunakan sebagai bahan kompos (Panjaitan at al., 2018). 


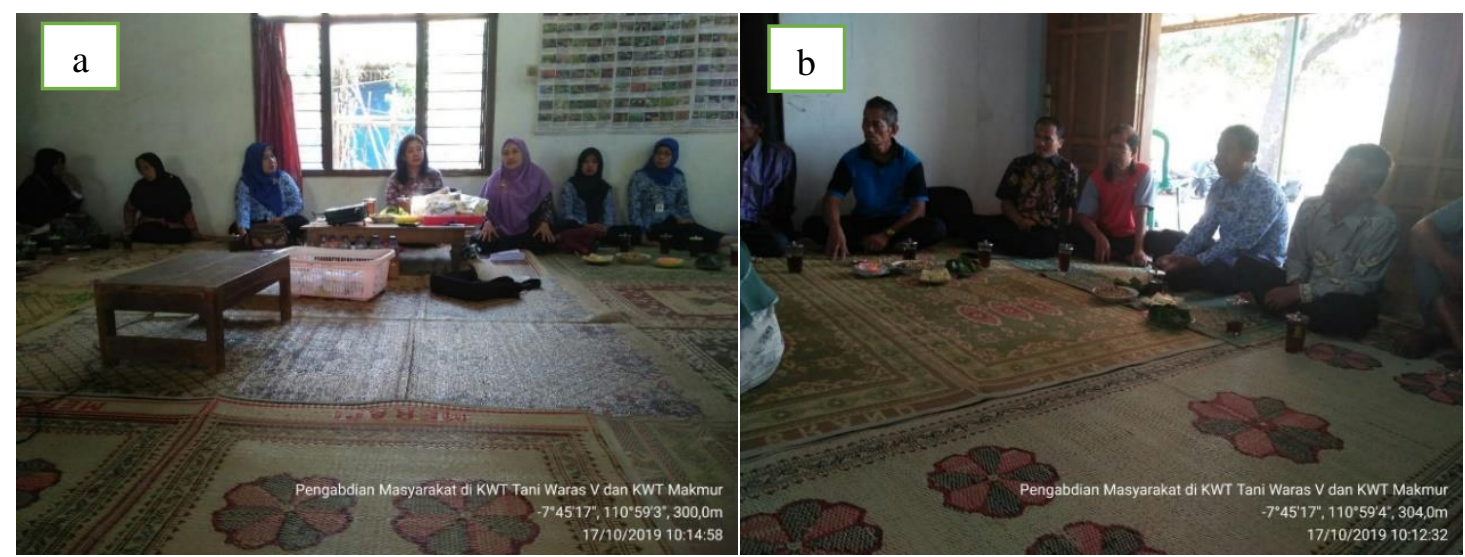

Gambar 10. Rapat evaluasi dan rancangan keberlanjutan, dihadiri Staf dari Dinas Pertanian Pangan dan Perikanan Kab. Karanganyar, Ibu-ibu KWT Tani Waras V, dan KWT Makmur (a) serta

Perwakilan bapak-bapak KT (b)

Pada kesempatan itu juga diberikan perhitungan keuntungan ekonomis jika ibu-ibu KWT dapat mengembangkan produksi nata menjadi bentuk usaha. Prospeknya sangat menguntungkan, diestimasikan untuk modal awal pembuatan nata de cassava hanya memerlukan biaya sekitar Rp 2.500,- untuk pembelian gula pasir, cuka dapur dan tauge, sedangkan untuk starter dan wadah sudah memperoleh dari Tim Pengabdian secara gratis. Berdasar hasil praktik, diperhitungkan 1 resep media fermentasi (terdiri $1 \mathrm{~L}$ media dari kulit singkong bagian dalam, $100 \mathrm{~g}$ gula pasir, $50 \mathrm{~mL}$ cuka dapur $25 \%$, dan $75 \mathrm{~mL}$ starter nata) dapat menghasilkan $1 \mathrm{~kg}$ nata segar, yang jika diolah dengan ditambah larutan gula 50\% dengan perbandingan nata dan larutan gula $1: 1$, akan menjadi $2 \mathrm{~kg}$ nata dalam larutan gula yang mempunyai nilai jual sekitar $\mathrm{Rp} 30.000,-/ \mathrm{kg}$. Sehingga dengan tambahan pengeluaran untuk pembelian 0,5 kg gula yaitu sekitar Rp 6000,dapat diestimasikan nilai keuntungan sekitar Rp $(2 \times 30.000)-R p(2.500+6.000)=R p 51.500,-$ per resep media fermentasi. Selain dari kulit singkong, ibu-ibu dari kedua KWT tersebut juga dapat menggunakan bahan media fermentasi lain yang tersedia berlimpah dari limbah cair dan ampas pembuatan mocaf dan rengginang singkong, dan juga dari sisa limbah dapur keseharian lainnya yang juga telah diuji dan dibuktikan bersama bahwa dapat dijadikan media pembuatan nata.

Terkait dengan biostarter kompos dan tentang kompos, ibu-ibu KWT dan bapak-bapak perwakilan KT dimantapkan pemahamannya tentang pentingnya menjaga, mempertahankan, bahkan meningkatkan kemampuan lahan secara berkelanjutan dengan masukan organik yang sangat esensial bagi kesehatan dan produktivitas lahan. Di akhir acara, tim pengabdian dan mitra sepakat untuk tetap menjalin komunikasi dan kerja sama untuk keberlanjutan usaha pertanian.

\section{KESIMPULAN}

Kesimpulan yang diperoleh dari hasil kegiatan pengabdian di KWT Tani Waras V Desa Jatisobo dan KWT Makmur Desa Jatimulyo, Kecamatan Jatipuro dapat dikristalkan dari aspek keberhasilan TTG transformasi kulit singkong menjadi nata de cassava dan biostarter kompos, dan dari aspek respons dan keberhasilan ibu-ibu peserta kegiatan pengabdian dalam memahami dan mempraktikkan TTG tersebut. Kulit singkong sebagai limbah produksi mocaf dan rengginang singkong terbukti dapat dimanfaatkan menjadi 2 produk bermanfaat yaitu nata de cassava dan biostarter kompos. Pengolahan kulit singkong (lapisan dalam) menjadi nata de cassava diperlukan perlakuan khusus perbandingan berat bahan kulit singkong dengan volume bahan fermentasi dan perlakuan pengendapan. Proses pembuatan harus dilakukan secara higienis, disiplin menjaga kebersihan untuk mencegah kontaminasi. Limbah kulit singkong (lapisan dalam dan luar, bagian bonggol) juga potensial dijadikan sumber isolat dekomposer kompos yang mampu mempercepat proses dekomposisi dalam pembuatan kompos berkualitas, dan sekaligus sebagai sumber biostarter kompos selanjutnya. Ibu-ibu KWT Tani Waras V dan KWT Makmur sangat antusias, bersemangat, berpartisiasi aktif dan berkontribusi nyata, ditunjukkan dengan 90-95\% anggota yang aktif mengikuti semua tahapan kegiatan pengabdian, sisanya karena sudah sepuh atau karena bekerja di luar desa. Semua tahapan pembuatan nata de 
cassava (100\%) sudah dipraktikkan oleh ibu-ibu KWT, bahkan mereka mampu mengembangkan dengan berbagai variasi resep termasuk menggunakan bahan limbah lainnya dengan tingkat keberhasilan 90-95\%. Ibu-ibu KWT dan dan perwakilan bapak-bapak KT diperdalam pemahaman tentang fungsi biostarter kompos dalam proses pengomposan, dan juga bertambah skill dalam perbanyakan biostarter kompos.

\section{UCAPAN TERIMA KASIH}

Ucapan terima kasih disampaikan kepada Universitas Sebelas Maret (UNS) yang mendukung pendanaan kegiatan Pengabdian ini melalui Hibah Pengabdian Skema Program Kemitraan Masyarakat (PKM) Sumber Dana PNBP UNS Tahun Anggaran 2019 dengan nomor kontrak 517/UN27.21/PM/2019.

\section{DAFTAR PUSTAKA}

Akanbi, W. B., Adebooye, C. O., Togun, A. O., Ogunrinde, J. O., \& Adeyeye, S. A. (2007). Growth, herbage, and seed yield and quality of Telfairia occidentalis as influenced by cassava peel compost and mineral fertilizer. World Journal of Agricultural Sciences, 3(4), 508-516.

Alfarisi, C. D., Yelmida, Zahrina, I., \& Mutamima, A. (2021). Production of nata de cassava from tapioca starch wastewater using different natural sources of nitrogen. Jurnal Ilmiah Pertanian, 17(2), 93-100. https://doi.org/10.31849/jip.v17i2.6208

Anindyawati, T. (2010). Potensi selulase dalam mendegradasi lignoselulosa limbah pertanian untuk pupuk organik. Berita Selulosa, 45(2), 70-77.

BPS Kabupaten Karanganyar. (2018). Ubi Kayu 2015-2017.

http://karanganyarkab.bps.go.id/linkTabl eDinamis/view/id/8

Cahyani, V. R., \& Kimura, M. (2009). Succession and phylogenetic composition of microbial communities responsible for the composting process of rice straw. In J. C. Pereira \& J. L. Bolin (Eds.), Composting: Processing, Materials and Approaches (pp. 69-112). Nova Science Publishers.

Cahyani, V. R., Matsuya, K., Asakawa, S., \& Kimura, M. (2003). Succession and phylogenetic composition of bacterial communities responsible for the composting process of rice straw estimated by PCR-DGGE analysis. Soil Science and Plant Nutrition, 49(4), 619630.

https://doi.org/10.1080/00380768.2003.1 0410052

Cahyani, V. R., Matsuya, K., Asakawa, S., \& Kimura, M. (2004a). Succession and phylogenetic profile of eukaryotic communities in the composting process of rice straw estimated by PCR-DGGE analysis. Biology and Fertility of Soils, 40, 334-344. https://doi.org/10.1007/s00374004-0783-x

Cahyani, V. R., Matsuya, K., Asakawa, S., \& Kimura, M. (2004b). Succession and phylogenetic profile of methanogenic archaeal communities during the composting process of rice straw estimated by pcr-dgge analysis. Soil Science and Plant Nutrition, 50(4), 555563.

https://doi.org/10.1080/00380768.2004.1 0408512

Cahyani, V. R., Watanabe, A., Matsuya, K., Asakawa, S., \& Kimura, M. (2002). Succession of microbiota estimated by phospholipid fatty acid analysis and changes in organic constituents during the composting process of rice straw. Soil Science and Plant Nutrition, 48(5), 735743.

https://doi.org/10.1080/00380768.2002.1 0409264

Cardoso, A. P., Mirione, E., Ernesto, M., Massaza, F., Cliff, J., Rezaul Haque, M., \& Bradbury, J. H. (2005). Processing of cassava roots to remove cyanogens. Journal of Food Composition and Analysis, 18(5), 451-460. https://doi.org/10.1016/j.jfca.2004.04.002

Mayasti, N. K. I., \& Nugroho, D. A. (2013). Pemanfaatan ampas basah tapioka sebagai media fermentasi dalam pembuatan nata de cassava. Pangan, 22(4), 365-372.

Oboh, G. (2006). Nutrient enrichment of cassava peels using a mixed culture of Saccharomyces cerevisae and Lactobacillus spp solid media fermentation techniques. Electronic Journal of Biotechnology, 9(1), 46-49.

Panjaitan, E., Manalu, C. J., \& Damanik, S. P. (2018). Effect of mycorrhizae and kirinyu (Chromolaena odorata L.) compost on the production of red onion in ultisol soil. IOP 
Conference Series: Earth and Environmental Science, 205(1). https://doi.org/10.1088/17551315/205/1/012017

Permatasari, A. S., Winaningsih, I., \& Prasetiyo, J. A. (2019). Inovasi limbah cair singkong menjadi nata de cassava sebagai bisnis kuliner. Jurnal Pengabdian Kepada Masyarakat (Indonesian Journal of Community Engagement), 5(3), 398-415. https://doi.org/10.22146/jpkm.42397

Resimanuk, Y. H., Nizar, A., \& Despita, R.
(2018). Pemanfaatan limbah kulit singkong menjadi dendeng kulit singkong dengan penambahan berbagai sumber protein. Agriekstensia, 17(1), 1-9.

Sandi, S. (2010). Kandungan serat kasar kulit bagian dalam singkong yang mendapat perlakuan bahan pengawet selama penyimpanan. Jurnal Sain Peternakan Indonesia, 5(2), 123-128. https://doi.org/10.31186/jspi.id.5.2.123128 